\title{
СЕЗОННЫЕ ИЗМЕНЕНИЯ МИКРОБИОМА РУБЦА У СЕВЕРНОГО ОЛЕНЯ (Rangifer tarandus) В УСЛОВИЯХ РОССИЙСКОЙ АРКТИКИ*
}

\author{
Л.А. ИЛЬИНА', В.А. ФИЛИППОВА', К.А. ЛАЙШЕВ², Е.А. ЙЫЛДЫРЫМ', \\ Т.П. ДУНЯШЕВ1', Е.А. БРАЖНИК'1, А.В. ДУБРОВИН1', Д.В. СОБОЛЕВ1, \\ Д.Г. ТЮРИНА', Н.И. НОВИКОВА' 1 , Г.Ю. ЛАПТЕВ1', А.А. ЮЖАКОВ², \\ Т.М. РОМАНЕНКО ${ }^{3}$, Ю.П. ВЫЛКО 3
}

Северный олень (Rangifer tarandus) - крупное голарктическое травоядное животное, особенности условий обитания которого, в том числе низкие температур и скудные рационы, обусловили эволюционное развитие уникальной рубцовой микробиоты, необходимой для эффективного усвоения арктической флоры. В зимний период большую долю кормовых растений северного оленя составляют лишайники, богатые вторичными метаболитами, которые могут влиять на представителей микробного консорциума пищеварительного тракта. Ранее сообщалось о токсическом действии некоторых метаболитов лишайников (например, усниновой кислоты) на ряд микроорганизмов (Clostridiales, Enterococcus, Staphylococcus aureus, Escherichia coli и др.), а также на жвачных животных (лосей). Однако о влиянии потребления лишайников на микробиом рубца северных оленей мало что известно. Нами с применением молекулярно-биологического анализа впервые были исследованы сезонные закономерности формирования микробных сообществ рубца северных оленей $\boldsymbol{R}$. tarandus, обитающих в условиях Российской Арктики. Цель исследования - сравнение состава бактериального сообщества рубца северных оленей в летне-осенний и зимне-весенний периоды с использованием метода NGS-секвенирования. При анализе микробных сообществ оценивали биоразнообразие, таксономическую структуру, а также взаимозависимость этих показателей с особенностями питания северного оленя в связи со сменой сезона. Образцы содержимого рубца отбирали в летне-осенний и зимне-весенний периоды в 2017-2018 годах у 20 особей ненецкой породы (4-8-месячные телята и взрослые животные в возрасте 3-6 лет, $n=3$ для каждой возрастной групाы) в Ненецком автономном округе (АО). Сезонные, но не половозрастные различия оказались основным фактором влияния на бактериальное сообщество рубца северных оленей, что, по всей видимости, обусловлено неодинаковым составом пастбищного рациона. В летне-осенний период отмечено достоверное повышение показателей $\alpha$-биоразнообразия микробиома рубца по сравнению с зимне-весенним по числу ОTUs (Operational Taxonomic Units), индексам Сhaо1 и Шеннона. Сопоставление $\beta$-разнообразия микробиоты рубца северных оленей продемонстрировало наличие выраженной кластеризации образцов по сезонам года. Несмотря на то, что в зимний период рацион северных оленей был представлен преимущественно лишайниками, которые не являются типичным кормом для других жвачных (крупного рогатого скот, овец и др.), было интересно отметить, что в целом полученный микробиомный профиль соответствовал современным представлениям о микробиоте рубца жвачных животных. Тем не менее в разные сезонные периоды отмечены значимые изменения представленности ряда таксонов, наиболее четкие из которых были детектированы для микроорганизмов, ассоциированных с процессами ферментации полисахаридов корма. Так, в зимне-весенний сезон выявлено достоверное увеличение обилия микроорганизмов, разлагающих полисахариды лишайников, в том числе гемицеллюлозу (Butyrivibrio, Ruminococcus) и лихенин (Succiniclasticum, Paraprevotellaceae, Prevotella). В летние-осенний период отмечается достоверное увеличение доли целлюлозолитических бактерий Clostridium, Blautia, Clostridiales, Christensenellaceae, Mogibacteriaceae, Prevotellaceae. Кроме того, показано, что в летний период в рубце северного оленя развивается группа микроорганизмов, которые относятся к возбудителям инфекций (Erysipelotrichaceae, Coriobacteriaceae, Mycoplasmataceae, Rickettsiales). В целом полученные результаты позволяют сделать вывод о достаточно четкой ассоциации микробиома рубца северного оленя с особенностями питания в разные сезоны, определяющей адаптацию животных к экологическим условиям.

Ключевые слова: Rangifer tarandus, северный олень, рубец, микробиом, сезонность, NGSсеквенирование, Российская Арктика.

Важнейшая проблема физиологии северного оленя связана со скудностью рациона (особенно в период длительного холодного сезона), которая усугубляется суровостью погодных условий. Дефицит доступных кормов определяет одну из причин смертности северных оленей в зимний период

\footnotetext{
* Исследование выполнено при поддержке гранта РНФ для реализации научного проекта № 17-76-20026 «Микробиоценоз рубца Rangifer tarandus Арктических регионов России как фундаментальная основа получения перспективных биотехнологий для сельскохозяйственных животных».
} 
$(1,2)$. Состав кормовой базы северного оленя значительно различается по сезонам. В летне-осенний период основу рациона может составлять до 300 видов растений, включая злаки, осоки, листья ив, карликовых берез. На лишайники при этом приходится не более $15 \%$. В зимне-весенний период доля лишайников в рационе северных оленей возрастает до $75 \%$, а остальные 25-30 \% - это остатки зеленых растений, мхи, веточные корма и различные примеси (2). Лишайники крайне бедны питательными веществами, азотистыми и минеральными соединениями, что приводит к замедлению роста и развития молодняка, истощению животных, особенно переболевших в летний период, стельных важенок и быков $(3,4)$. Кроме того, лишайники продуцируют вторичные метаболиты - органические соединения с бактерицидной активностью, в частности усниновую кислоту $(5,6)$. Некоторые исследователи отмечают ее токсичное действие на животных. Так, сообщалось о гибели 300 лосей вследствие употребления лишайников при отсутствии альтернативного корма (7). Также известно, что усниновая кислота в высокой концентрации токсична для овец (8). Однако установлено, что северные олени могут употреблять лишайники без негативных последствий (9) благодаря способности анаэробных микроорганизмов рубца к детоксикации вторичных фенольных метаболитов лишайников (10). При этом усниновая кислота и ее метаболиты не обнаруживаются в содержимом рубца, моче и экскрементах северного оленя (10). Перечисленные факты обусловливают интерес к углубленному изучению физиологических особенностей питания этих жвачных животных, и прежде всего их уникальной рубцовой микробиоты, необходимой для эффективного усвоения арктической флоры.

Проведенные ранее зарубежными авторами исследования различных представителей жвачных позволили выявить, что состав микробиома рубца может зависеть от многих факторов, в числе которых генотип животных (11), возраст (12), местообитание $(13)$, сезон года $(4,14)$, рацион и режим кормления (15), состояние здоровья, применение антимикробных соединений (16), световой режим суток (17), стресс (18) и условия окружающей среды (19). Поэтому, без сомнения, изучение адаптационных приспособлений северных оленей должно опираться на оценку условий их местообитания, питания и других факторов.

Об изменениях состава микробиома рубца северных оленей в зимний период, связанных с увеличением доли потребления лишайников, мало что известно. Результаты, полученные M.A. Olsen с соавт. (20) на основе классических микробиологических методов, продемонстрировали снижение общего количества микроорганизмов в рубце северных оленей Rangifer tarandus platyrhynchus в зимний период по сравнению с летним на порядок. Аналогичные результаты по снижению в зимний период численности жизнеспособных зооспор хитридиомицетов описаны также для других видов жвачных $(21,22)$.

Результаты молекулярно-генетических исследований микробиома желудочно-кишечного тракта вступают в некоторое противоречие с данными, полученными с помощью культуральных методов. Так, сообщалось о значимом изменении представленности некоторых микроорганизмов в рубце северного оленя в зависимости от сезона (23). Показано, что в зимний период доля целлюлозолитических бактерий Butyrivibrio fibrisolvens повышалась (22\% летом и 30 \% зимой), тогда как амилолитических бактерий Streptococcus bovis - снижалась (17 \% летом и 4 \% зимой). Другие авторы, напротив, не выявили значимых изменений в биоте рубца у Rangifer tarandus 
platyrhynchus архипелага Шпицберген по количеству метаногенов, бактерий и простейших в связи со сменой состава растительности естественных пастбищ в осенний и весенний период (24). Аналогичные результаты получили A. Salgado-Flores c соавт. (25) при оценке различий в микробиоте рубца и слепой кишки северных оленей Rangifer tarandus tarandus, обитающих на территории Норвегии, при скармливании лишайников и гранулированных кормов. Авторы установили отсутствие значимого влияния рациона на численность основных групп микроорганизмов (бактерий, грибов, архей), но тем не менее показали наличие существенных различия по составу бактериального и археотного сообществ как в рубце, так и в слепой кишке. В частности, в рубце животных, которые получали лишайниковый рацион, отмечено достоверное снижение доли некоторых бактерий рода Ruminococcus, порядка Bacteroidales, принимающих участие в процессах разложения растительной клетчатки.

Мы впервые применили молекулярно-биологический анализ для изучения сезонных особенности формирования бактериальных сообществ рубца у северных оленей Rangifer tarandus из Российской Арктики. В результате проведенного исследования охарактеризована приуроченность изменений микробиоты к структуре кормовой базы и их связь с половозрастными различиями. Впервые показано, что сезонные изменения - один из ключевых факторов формирования микробиом рубца у северного оленя, что, вероятно, связано с особенностями кормовой базы животных.

Цель работы - сравнительная оценка состава бактериального сообщества рубца северных оленей регионов Арктической зоны России в летнеосенний и зимне-весенний периоды с использованием метода NGS-ceквенирования.

Методика. Объектом исследования были 20 особей северного оленя (Rangifer tarandus) ненецкой породы, в том числе телята (возраст 4-8 мес) и взрослые особи (3-6 лет). Образцы содержимого рубца отбирали в летнеосенний и зимне-весенний период в 2017 и 2018 годах $(n=3$ для каждой возрастной группы животных) в Ненецком автономном округе (AO) (п. Нельмин-Нос, тундровая природно-климатическая зона). В те же сроки в летне-осенний и зимне-весенний периоды отбирали образцы пастбищной растительности, составляющей основу рациона северных оленей. Проводили ботаническое описание образцов растительности по «Определителю кормовых растений северного оленя» (26), учитывали соотношение различных видов растительности в рационе и его питательность (27).

Для анализа состава бактериального сообщества рубца северных оленей методом NGS-секвенирования (Next generation sequencing) из образцов выделяли тотальную ДНК, используя набор Genomic DNA Purification Kit («Fermentas, Inc.», Литва) согласно рекомендациям производителя. Конечную концентрацию тотальной ДНК в растворе измеряли на флуориметре Qubit («Invitrogen, Inc.», США) с наборами Qubit dsDNA BR Assay Kit («Invitrogen, Inc.», США) в соответствии с рекомендациями производителя.

NGS-секвенирование проводили на платформе для секвенирования следующего поколения MiSeq («Illumina, Inc.», США) с праймерами для V3V4 региона 16S рPHK; прямой праймер - 5'-TCGTCGGCAGCGTCAGATGTGTATAAGAGACAGCCTACGGGNGGCWGCAG-3'; обратный праймер - 5'-GTCTCGTGGGCTCGGAGATGTGTATAAGAGACAGGACTACHVGGGTATCTAATCC-3'.

Для приготовления библиотек использовали реагенты Nextera® XT 
IndexKit («Illumina, Inc.», США), для очистки ПЦР-продуктов - Agencourt AMPure XP («Illumina, Inc.», США), для проведения секвенирования MiSeq ${ }^{\circledR}$ ReagentKit v2 (500 cycle) («Illumina, Inc», США).

Обработку полученных ридов (фильтрация по качеству Q30, триммирование праймеров) выполняли с помощью биоинформатической платформы Illumina («Illumina, Inc», США). Контроль качества ридов, оценку таксономического состава бактерий проводили в программе QIIME2 v.2019.10 (https://docs.qiime2.org) с использованием базы данных GreenGenes версии 13.5 (https://greengenes.secondgenome.com).

Для сравнения бактериальных сообществ рассчитывали показатели $\alpha$ - и $\beta$-разнообразия. Для оценки $\alpha$-разнообразия вычисляли индексы видового богатства (число OTUs - Operational Taxonomic Units, индекс обилия Chao 1) и индекс разнообразия Шеннона в программном обеспечении QIIME2 (28) с использованием параметров по умолчанию. Дополнительно определяли число общих и уникальных OTUs для образцов, сгруппированных по сезонному признаку, с использованием пакета VennDiagram (29) в программном обеспечении R (https://bioinfogp.cnb.csic.es/tools/venny/index.html). $\beta$-Разнообразие бактериальных сообществ оценивали в программном обеспечении R с применением алгоритма неметрического многомерного шкалирования NMDS (nonmetric multidimensional scaling) (30) с использованием метрики расстояния Брея-Кеертиса из пакета «vegan» (RDocumentation. Package 'vegan', 2019, https://cran.r-project.org/web/packages/vegan/vegan.pdf).

Тепловые карты, характеризующие различия в составе микробиома рубца в зимний и летний сезоны, строили с применением пакета «pheatmap» Version 1.0.12 для программного обеспечения R (https://cran.rproject.org/web/packages/pheatmap/pheatmap.pdf). При построении тепловых карт центрировали и масштабировали числовую матрицу по строкам и выполняли иерархическую кластеризацию по алгоритму Уорда (Ward's method) на основании матрицы квадрата евклидовых расстояний.

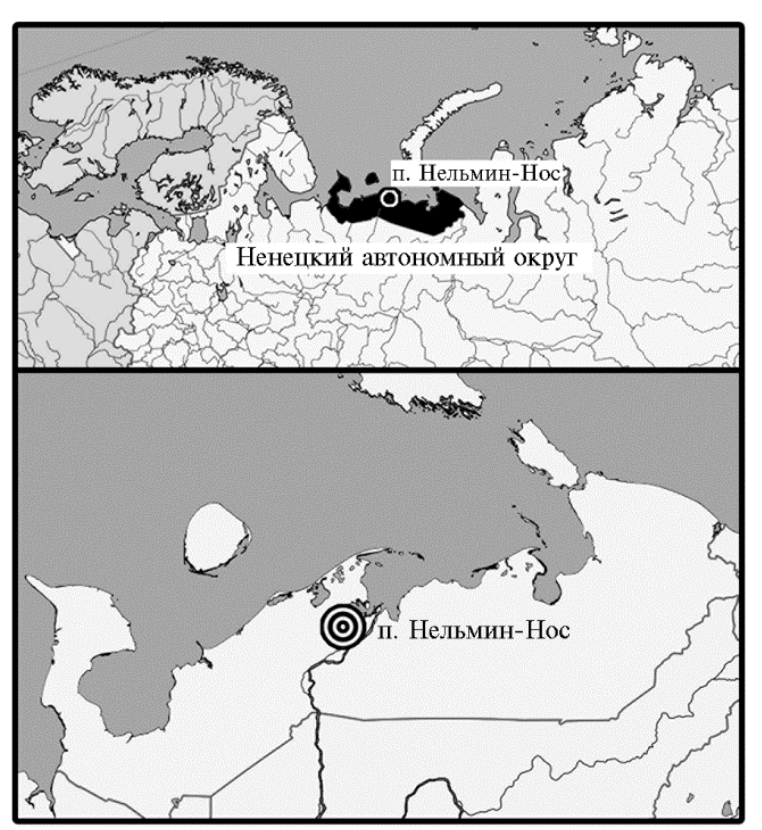

Рис. 1. Регион отбора образцов содержимого рубца северных оленей Rangifer tarandus ненецкой породы (Ненецкий автономный округ, 2017 и 2018 годы).

Результаты NGS-секвенирования бактериального сообщества рубца северного оленя были депонированы в NCBI (National Center for Biotechnology Information) на cepвисе BioProject в Sequence Read Archive (SRA) под номером PRJNA576999.

Статистический анализ данных осуществляли с применением программного обеспечения Microsoft Excel 2010. Приведены средние значения показателей $(M)$ и их стандартные ошибки ( \pm SEM). Достоверность различий оценивали при помощи $t$-критерия Стьюдента.

Результаты. На рисунке 1 показано место в Ненецком АO, где осуществляли отбор образцов. Усредненный со- 
став и питательность летне-осеннего и зимне-весеннего пастбищного рациона северных оленей представлены в таблице 1.

1. Усредненный состав и питательность пастбищного рациона северных оленей (Rangifer tarandus) ненецкой породы по сезонам года $(M \pm \mathrm{SEM}$, Heнецкий АО, 2017-2018 годы)

\begin{tabular}{|c|c|c|}
\hline Показатель & Летне-осенний сезон & Зимне-весенний сезон \\
\hline \multicolumn{3}{|c|}{ Показ атели питательности } \\
\hline Растворимые углеводы (сахара), г/кг & $66,86 \pm 3,50$ & $40,22 \pm 1,82$ \\
\hline Массовая доля сухого вещества, \% & $82,04 \pm 1,46$ & $79,15 \pm 3,01$ \\
\hline Сырой жир, г/кг & $15,46 \pm 0,54$ & $10,62 \pm 0,26$ \\
\hline Сырой протеин, г/кг & $64,03 \pm 3,50$ & $40,69 \pm 1,40$ \\
\hline Сырая зола, г/кг & $23,95 \pm 1,80$ & $30,95 \pm 1,12$ \\
\hline Сырая клетчатка, г/кг & $160,55 \pm 8,60$ & $168,45 \pm 7,40$ \\
\hline \multicolumn{3}{|c|}{ Компоненты рациона } \\
\hline Лишайники рода Кладония (Cladonia) & 10 & 75 \\
\hline Береза обыкновенная (Betula pendula Roth) & 20 & 5 \\
\hline Ива северная (Salix borealis Fries) & 15 & - \\
\hline Голубика обыкновенная (Vaccinium uliginosum L.) & 5 & 5 \\
\hline Береза карликовая (Betula nana L.) & 20 & - \\
\hline Смесь многолетних трав & 30 & 15 \\
\hline
\end{tabular}

В таблице 2 приведена характеристика образцов содержимого рубца северного оленя, изученных методом NGS-секвенирования.

2. Образцы содержимого рубца северных оленей (Rangifer tarandus) ненецкой породы по сезонам года, исследованные методом NGS-секвенирования (Ненецкий АО, 2017-2018 годы)

\begin{tabular}{l|llll}
\hline \multicolumn{1}{c}{ Номер образца } & Число прочтений & Сезон отбора образцов & \multicolumn{1}{c|}{ Возраст } & Пол \\
\hline 7SNAM & 86227 & Летне-весенний & Взрослая особь & Хор \\
12SNAF & 84970 & Летне-осенний & Взрослая особь & Важенка \\
8SNAM & 81850 & Летне-осенний & Взрослая особь & Хор \\
16SNCM & 77574 & Летне-осенний & Теленок & Хор \\
15SNCM & 76548 & Летне-осенний & Теленок & Хор \\
14SNAF & 57229 & Летне-осенний & Взрослая особь & Важенка \\
10SNAF & 56651 & Летне-осенний & Взрослая особь & Важенка \\
13SNCM & 54770 & Летне-осенний & Теленок & Хор \\
9SNAM & 44070 & Летне-осенний & Взрослая особь & Хор \\
11SNAF & 41268 & Летне-осенний & Взрослая особь & Важенка \\
16WNAF & 31759 & Зимне-весенний & Взрослая особь & Важенка \\
15WNAF & 29221 & Зимне-весенний & Взрослая особь & Важенка \\
20WNAM & 28141 & Зимне-весенний & Взрослая особь & Хор \\
18WNCM & 26760 & Зимне-весенний & Теленок & Хор \\
19WNCM & 26538 & Зимне-весенний & Теленок & Хор \\
22WNAM & 25629 & Зимне-весенний & Взрослая особь & Хор \\
14WNAF & 24944 & Зимне-весенний & Взрослая особьь & Важенка \\
17WNCM & 20437 & Зимне-весенний & Теленок & Хор \\
13WNAF & 17683 & Зимне-весенний & Взрослая особь & Важенка \\
21WNAM & 14443 & Зимне-весенний & Взрослая особь & Хор \\
\hline
\end{tabular}

Северные олени - единственные животные, которые могут эффективно использовать скудные растительные ресурсы обширных пространств тундры, лесотундры, северной тайги (31). Одна из особенностей рациона этих животных - высокая доля лишайников. Скудность северного рациона заставляет северных оленей даже в летний период активно поедать различные виды лишайников $(1,2)$, содержащие большое количество их токсичных метаболитов, например усниновой кислоты (9). При этом в зимний период доля лишайников в рационе северного оленя может достигать $75 \%$ (2). Лишайники, состоящие из грибов и водорослей, химически и структурно очень отличаются от сосудистых растений. У растений клеточные стенки состоят в основном из целлюлозы (34-68 \%), гемицеллюлозы (34$60 \%$ ) и лигнина (5-17 \%) (32), тогда как у лишайников - преимущественно из гемицеллюлозы и лихенина (3). 
Известно, что в рубце жвачных бактерии составляют наиболее крупную фракцию, которая разнообразна по таксономическому составу и спектру продуцируемых ферментов, необходимых для усвоения растительных полисахаридов (33-35). В связи с этим в представленном исследовании нами впервые было изучено изменение структуры бактериального сообщества рубца северных оленей в разные сезонные периоды. Для исследований был выбран метод высокопроизводительного секвенирования (NGS-секвенирование), применение которого ранее позволило ряду авторов $(11,36)$ существенно расширить информацию о составе рубцового микробиома жвачных, в том числе северного оленя, по сравнению с классическими культуральными методами.

В результате NGS-секвенирования ДНК образцов мы получили библиотеку ридов, включающую 906712 последовательностей. Среднее число проанализированных последовательностей (ридов) в одном образце 45336, минимальное - 14443, максимальное - 86227. Секвенированные последовательности были de novo кластеризованы в операционные таксономические единицы OTE (OTUs) с порогом идентичности $97 \%$.

3. Характеристика $\alpha$-биоразнообразия бактериального сообщества рубца у северных оленей (Rangifer tarandus) ненецкой породы по результатам NGS-ceквенирования ( $M \pm \mathrm{SEM}$, Ненецкий автономный округ, 2017-2018 годы)

\begin{tabular}{|c|c|c|c|}
\hline Параметр & \multicolumn{2}{|c|}{ Величина показателя по группам сравнения } & p-value* \\
\hline \multicolumn{4}{|c|}{ Фактор сезонных различй̆ } \\
\hline Группа сравнения & Зимне-весенний период & Летне-осенний период & \\
\hline Индекс Шеннона & $7,68 \pm 0,09$ & $8,26 \pm 0,06$ & 0,0000523 \\
\hline OTUs & $423,90 \pm 25,03$ & $535,00 \pm 24,14$ & 0,0075542 \\
\hline Индекс Chaol & $435,71 \pm 25,87$ & $548,82 \pm 25,09$ & 0,0084612 \\
\hline \multicolumn{4}{|c|}{ Фактор воз растных различи й } \\
\hline Группа сравнения & Телята & Взрослые особи & \\
\hline Индекс Шеннона & $8,03 \pm 0,10$ & $7,95 \pm 0,11$ & 0,7685305 \\
\hline OTUs & $497,67 \pm 7,87$ & $471,64 \pm 30,19$ & 0,5885066 \\
\hline Индекс Chaol & $511,16 \pm 8,07$ & $484,17 \pm 31,08$ & 0,5963144 \\
\hline \multicolumn{4}{|c|}{ Фактор половых различи й } \\
\hline Группа сравнения & Хоры & Важенки & \\
\hline Индекс Шеннона & $8,01 \pm 0,10$ & $7,93 \pm 0,15$ & 0,4976555 \\
\hline OTUs & $482,33 \pm 24,90$ & $475,13 \pm 39,74$ & 0,8484414 \\
\hline Индекс Chaol & $495,60 \pm 25,85$ & $487,26 \pm 40,60$ & 0,8311257 \\
\hline
\end{tabular}

В таблице 3 представлены значения параметров $\alpha$-биоразнообразия (OTUs, индексы Chaol и Шеннона). Видно, что статистически значимые различия параметров $\alpha$-биоразнообразия бактериального сообщества в рубце северного оленя наблюдались между группами образцов, отобранных в разные сезоны. Так, коэффициенты биоразнообразия для образцов, собранных в летне-весенний период, были достоверно выше по сравнению с таковыми для образцов в зимне-весенний период по индексам Chaol $(\mathrm{p}=0,0084612)$, Шеннона $(\mathrm{p}=0,0000523)$ и числу OTUs $(\mathrm{p}=0,0075542)$. Достоверных различий по коэффициентам $\alpha$-биоразнообразия бактериального сообщества рубца в связи с половозрастными особенностями у северного оленя мы не выявили.

Полученные результаты оценки параметров биоразнообразия свидетельствуют не только о достоверном расширении качественного состава видов (OTUs) в летне-осенний период, но и о росте их относительной численности (или выравненности), что отражается индексом Шеннона, который учитывает видовое богатство и равномерность распределения OTUs (28). Увеличение значения индекса Chaol, который, помимо видового богатства, придает больший вес редким видам, также указывает на повышение 
биоразнообразия микробного сообщества рубца у северных оленей в летнеосенний период по сравнению с зимне-весенним.

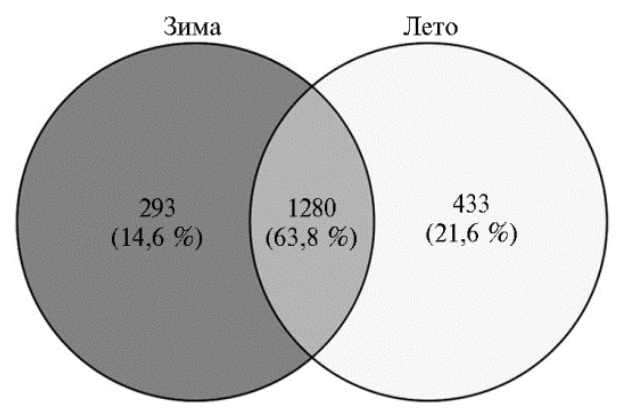

Рис. 2. Сравнительный анализ $\alpha$-разнообразия микробиома рубца у северных оленей (Rangifer tarandus) ненецкой породы в летне-осенний и зимне-весенний периоды с применением метода Venn graph analysis (Ненецкий АО, 2017-2018 годы).

кальных OTUs, в то время как в зимний период их число составило 1573.

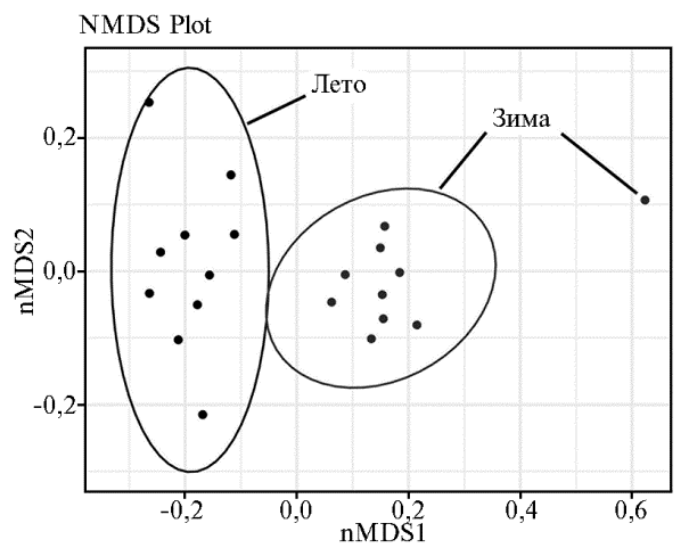

Рис. 3. Сравнительный анализ $\beta$-разнообразия микробиома рубца у северных оленей (Rangifer tarandus) ненецкой породы в летне-осенний и зимне-весенний периоды с применением метода NMDS (алгоритм неметрического многомерного шкалирования) (Ненецкий АО, 2017-2018 годы).

тверждается уникальность состава микробиома северного оленя в разные сезоны года.

Полученные результаты согласуются с данными исследований, где сообщалось о присутствии специфических микробных таксонов в пищеварительном тракте, которые могут варьироваться у животных одного вида или генотипа (37). Такие внутри- и межвидовые вариации в составе микробиоты могут служить индикаторами экологических процессов, которые формируют связанное с хозяином микробное сообщество. С учетом этого факт изменений показателей биоразнообразия в микробиоте рубца у исследованных нами особей подтверждает существующее мнение о том, что микробное сообщество может отражать физиологическое состояние животных. На наш взгляд, детектированные нами изменения рубцовой микробиоты у северных оленей логичны, поскольку питание - один из наиболее значимых факторов, влияющих на состав микробиома рубца жвачных $(11,33)$. 
На рисунке 4 в виде гистограммы показан состав бактериального сообщества рубца исследованных нами особей северных оленей на уровне филумов. В целом состав микробиома рубца был представлен 20 филумами бактерий.

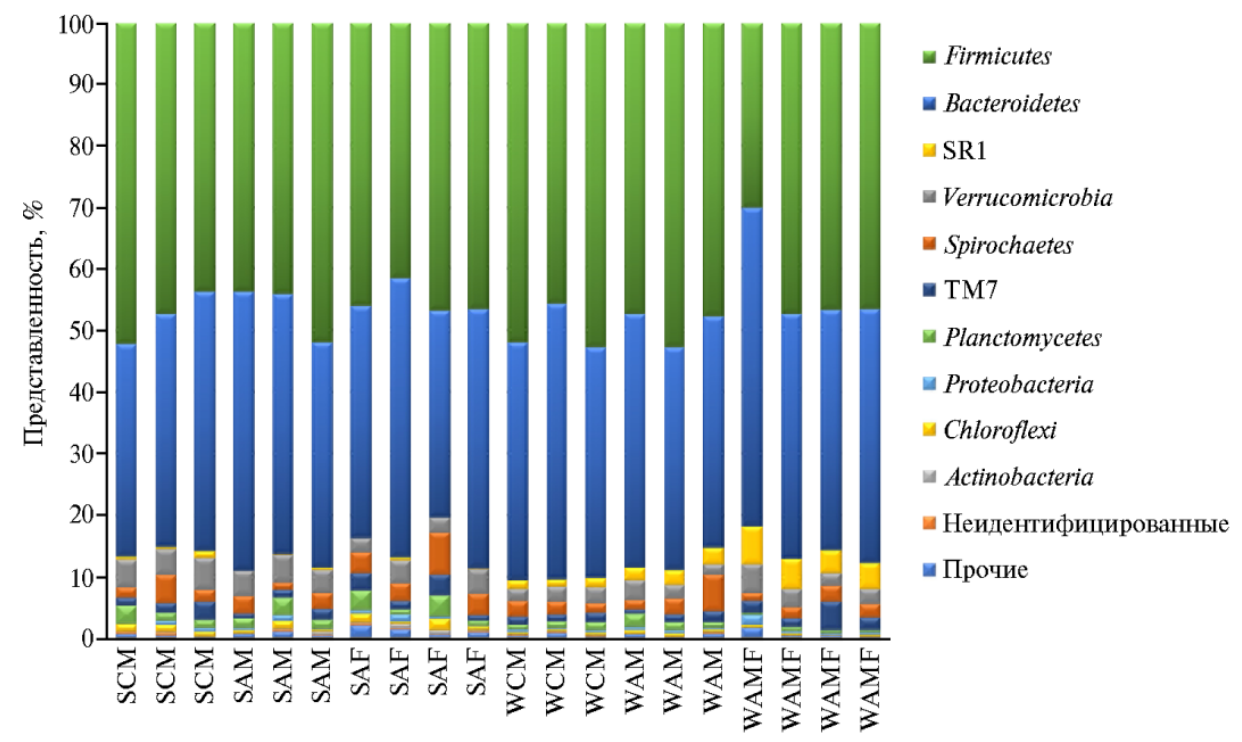

Рис. 4. Соотношение бактериальных филумов в микробиоме рубца у северных оленей (Rangifer tarandus) ненецкой породы в летне-осенний и зимне-весенний периоды: SCM, SAM, SAF - образцы летне-осеннего сезона от хоров-телят и взрослых особей - хоров и важенок; WCM, WAM, WAF - образцы зимне-весеннего сезона от хоров-телят и взрослых особей - хоров и важенок (Ненецкий АО, 2017-2018 годы).

На уровне филумов в сообществе доминировали представители Firmicutes (29,98-52,67 \%) и Bacteroidetes (33,55-51,87 \%), общая доля которых между сезонами достоверно не различалась. В меньшей степени в сообществе рубца оказались представлены бактерии филумов Proteobacteria $(0,20$ 1,64 \%), Verrucomicrobia (1,67-5,21\%), TM7 (0,69-4,67\%), Spirochaetes $(1,20-$ $6,88 \%)$, Actinobacteria (0,40-3,50\%), Planctomycetes $(0,27-3,50 \%)$ и SR1 $(0,14-$ 6,09\%). Доля бактерий из остальных филумов (Cyanobacteria, Nitrospirae, Chloroflexi, Synergistetes, Fibrobacteres, Fusobacteria, Elusimicrobia, Tenericutes, OD1, Synergistetes и 2 неидентифицируемых филума) составила менее $1 \%$ от всего бактериального сообщества.

На уровне семейства в большинстве образцов преобладали Ruminococcaceae (5,87-16,17 \%), Prevotellaceae (12,02-29,16 \%). Другие доминирующие таксоны с высокой относительной численностью включали неклассифицированные бактерии порядка Bacteroidales (9,76-16,00 \%) и семейства Clostridiales (4,31-15,83\%), Lachnospiraceae (4,17-14,29\%), Veillonellaceae (1,67-14,88\%).

На уровне рода доминирующее положение в рубце северного оленя занимали представители Prevotella (8,83-27,04 \%), Succiniclasticum (0,27-12,22 \%), неидентифицированные бактерии родов из семейств Veillonellaceae (0,21-2,71 \%), Lachnospiraceae (2,12-8,14 \%), Ruminococcaceae $(5,02-14,14 \%)$ и из порядков Clostridiales $(2,42-7,71 \%)$ и Bacteroidales $(9,64-$ $17,00 \%)$.

Интересно отметить у некоторых особей присутствие в минорных долях микроорганизмов, которые традиционно относятся к возбудителям 
различных заболеваний млекопитающих, в том числе членов семейств Fusobacteriaceae и Mycoplasmataceae.

Несмотря на то, что в зимний период рацион северных оленей был представлен преимущественно лишайниками, которые не являются типичным кормом для других жвачных (крупный рогатый скот, овцы и др.), важно отметить, что в целом полученные профили состава микробиома соответствовали современным представлениям о микробиоте рубца жвачных животных. Полученные нами данные служат прямым подтверждением результатов G. Henderson с соавт. (11), которые при изучении микробиомов рубца различных жвачных 32 видов и подвидов показали наличие у них корового сообщества, которое оставалось стабильным у всех изученных видов и подвидов. В составе корового сообщества рубца жвачных эти авторы отметили среди представителей филумов Firmicutes и Bacteroidetes бактерии родов Prevotella, Butyrivibrio и Ruminococcus. По их данными, число других микроорганизмов (например, бактерий семейств Lachnospiraceae, Ruminococcaceae, Bacteroidales и Clostridiales) менялось в зависимости от питания и окружающей среды, определяя тем самым уникальность каждого вида жвачных. При этом различия между группами животных, определяющие своего рода адаптацию к экологическим условиям, проявлялись на уровне минорных таксонов.

Стоит отметить важную физиологическую роль микроорганизмов филумов Firmicutes и Bacteroidetes в жизнедеятельности жвачных. Многие микроорганизмы, входящие в состав указанных таксонов (например, представители семейств Lachnospiraceae, Ruminococcaceae, Clostridiaceae, Bacteroidaceae и др.), - это активные продуценты ферментов (целлюлаз, гемицеллюлаз, ксиланаз, гликозидгидролаз и т.д.), которые организм хозяина не способен вырабатывать самостоятельно. Микробные ферменты позволяют организму жвачных усваивать широкий спектр растительных полисахаридов, обеспечивая организм животных летучими жирными кислотами (ЛЖК), такими как ацетат, пропионат, бутират, и другими питательными соединениями $(33,34)$.

Сообщалось, что пропорция филумов Firmicutes и Bacteroidetes в рубце жвачных зависит от места обитания и типа питания (13). Так, многие бактерии филума Firmicutes (родов Ruminococcus, Clostridium, Butirivibrio и др.) активно продуцируют целлюлозолитические ферменты, что позволяет им расщеплять растительную клетчатку, тогда как представители Bacteroidetes синтезируют преимущественно амилолитические ферменты и способствуют усвоению легко сбраживаемых углеводов (34). Пояэтому изменение представленности микроорганизмов перечисленных групп может также приводить к изменению спектра продуцируемых ими метаболитов, оказывая тем самым влияние на организм хозяина.

В нашем исследовании установлено, что смена сезонов вызывала значимые различия в численность микроорганизмов филумов Firmicutes и Bacteroidetes, а также ряда представителей других таксонов. На рисунках 5 и 6 представлены тепловые карты, отражающие представленность микроорганизмов, содержание которых в рубце северного оленя достоверно различалось в зимне-весенний и летне-осенний периоды.

Анализ данных, представленных на рисунке 5, показывает, что в летне-осенний период по сравнению с зимне-весенним доля представителей филумов SR1 $(0,33 \pm 0,11 \%$ против 3,09 $\pm 0,52 \%, r=0,00004, \mathrm{p}<0,05)$ и Planctomycetes $(0,01 \pm 0,006 \%$ против 0,24 $\pm 0,15 \%, r=0,02, \mathrm{p}<0,05)$ была достоверно меньше. 


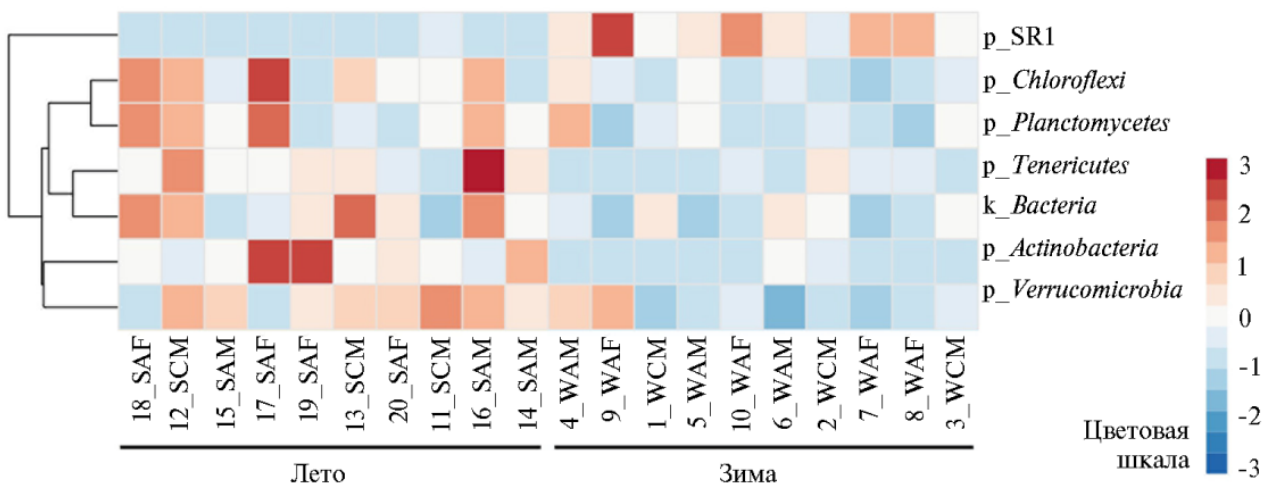

Рис. 5. Тепловая карта, отражающая различия в представленности филумов бактерий в образцах содержимого рубца у северных оленей (Rangifer tarandus) ненецкой породы в летне-осенний и зимне-весенний периоды: $\mathrm{S}$ - летний, W - зимний, A - взрослая особь, C - молодняк, М хор, F - важенка; k - царство, p - филум (Ненецкий АО, 2017-2018 годы).

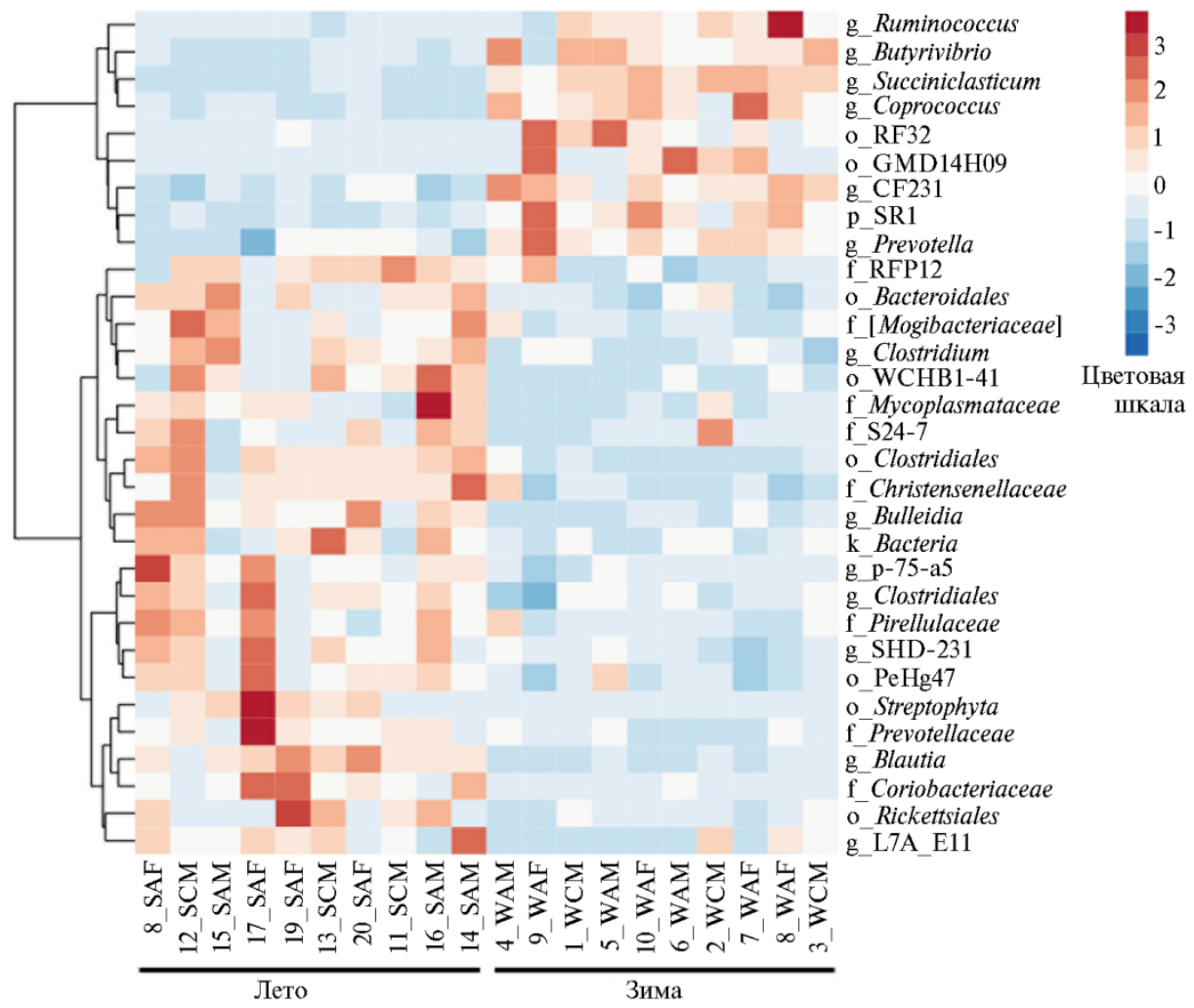

Рис. 6. Тепловая карта, отражающая различия в представленности родов бактерий в образцах содержимого рубца у северняых оленей (Rangifer tarandus) ненецкой породы в летне-осенний и зимне-весенний периоды: $\mathrm{S}$ - летний, $\mathrm{W}$ - зимний, $\mathrm{A}-$ взрослая особь, $\mathrm{C}-$ молодняк, $\mathrm{M}-$ хор, F - важенка; g - род, $\mathrm{f}$ - семейство, о - порядок, $\mathrm{k}$ - царство, $\mathrm{p}-$ филум (Ненецкий АО, 2017-2018 годы).

В зимне-весенний период отмечали достоверное снижение представленности ряда филумов, в том числе Actinobacteria $(0,26 \pm 0,08 \%$ против $0,03 \pm 0,01 \%, r=0,004)$, Chloroflexi $(0,95 \pm 0,15 \%$ против $0,43 \pm 0,06 \%, r=0,004)$, Tenericutes $(3,10 \pm 0,08 \%$ против $0,05 \pm 0,02 \%, r=0,006)$, Verrucomicrobia $(0,27 \pm 0,06 \%$ против $0,09 \pm 0,03 \%, r=0,01)$, неидентифицируемой филы 
$(1,96 \pm 0,32 \%$ против $1,01 \pm 0,24 \%, r=0,02)$; для всех $r \mathrm{p}<0,05$. Как закономерность, необходимо отметить снижение доли бактерии филумов Actinobacteria, Verrucomicrobia и Chloroflexi в рубце в зимний период (по мнению ряда исследователей, эти микроорганизмы ассоциированы с почвенными и растительными экосистемами) (38).

Кроме того, по результатам нашего исследования, общая доля доминирующих в рубце северного оленя бактерий филумов Firmicutes и Bacteroidetes в целом не показала достоверных различий в связи со сменой сезона. Однако, как видно из рисунка 6, на более низком таксономическом уровне численность некоторых представителей указанных таксонов в зимний период достоверное вовзрастала. Интересно, что достоверные различия были выявлены прежде всего для микроорганизмов, ассоциированных с процессами ферментации растительных полисахаридов. Так, в зимний период в рубце северного оленя происходило значимое увеличение количества бактерий родов Succiniclasticum (от $1,59 \pm 0,26 \%$ в летне-осенний период до $9,55 \pm 0,68 \%$ в зимне-весенний, $r=0,000000001$ ), Paraprevotellaceae (от $1,08 \pm 0,14 \%$ до $2,41 \pm 0,20 \%, r=0,00002$ ), Coprococcus (от $0,08 \pm 0,03 \%$ до

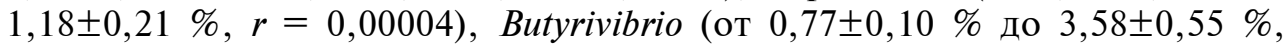

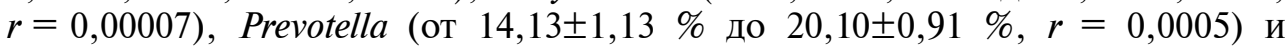

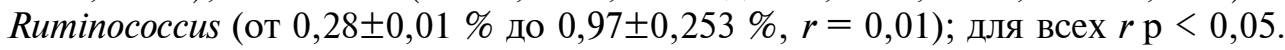

Напротив, доля целого набора других микроорганизмов из филумов Firmicutes и Bacteroides в зимний период существенно снижалась, Такие закономерности наблюдались в отношении представителей родов Clostridium

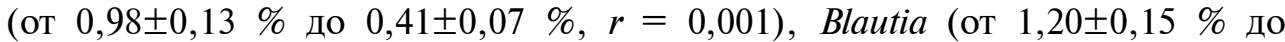
$0,18 \pm 0,04 \%, r=0,000006)$, неидентифицируемых родов из порядка Clostrid-

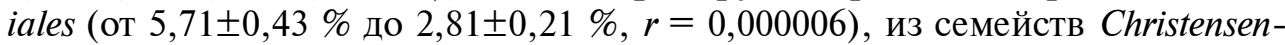

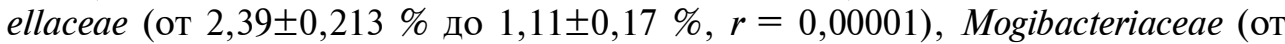
$2,23 \pm 0,41 \%$ до $0,89 \pm 0,19 \%, r=0,007$ ) и Prevotellaceae (от 3,29 $\pm 0,50 \%$ до $1,99 \pm 0,17 \%, r=0,02)$; для всех $r \mathrm{p}<0,05$.

Полученные нами данные подтверждают мнение G. Henderson c coавт. (11) о том, что различия в микробиоме рубца жвачных, определяющие своего рода адаптацию к экологическим условиям проявляются на уровне минорных таксонов.

Анализируя результаты нашего исследования, можно сделать вывод о достаточно четкой ассоциации микробиома рубца северного оленя с особенностями питания в разные сезоны. Учитывая, что лишайники состоят в основном из структурных углеводов $(3,32)$, таких как гемицеллюлоза, представляется закономерным преобладание в рубце в зимне-весенний период бактерий родов Butyrivibrio и Ruminococcus, гидролизующих указанный полисахарид. Известно, что роль в рубцовом микробиоме других бактерий представителей родов Prevotella и Paraprevotella из филума Bacteroidetes связана с деградацией крахмалистых полисахаридов посредством синтеза амилаз (39). Рост их представленности в зимний период может быть закономерен в связи с высоким содержанием в рационе северного оленя крахмала лишайников - лихенина. Также интересен обнаруженный факт роста представленности превотелл в рубце китайского пятнистого оленя, рацион которого включал большое количество листьев дуба, содержащих значительное количество вторичных метаболитов растений с антимикробным действием (40).

Необходимо отметить, что численность другого представителя превотелл (неидентифицируемого рода из семейства Prevotellaceae) в рубце ceверного оленя была, напротив, выше в летне-осенний период (см. рис. 6). 
Это может объясняться высокой вариабельностью генома микроорганизмов указанного семейства, вследствие чего бактерии разных родов и видов превотелл проявляют способность синтезировать широкий спектр ферментов, гидролизующих растительные полисахариды. Таким образом, повышение представленности бактерий выявленного нами представителя превотелл в летне-осенний период возможно благодаря его способности к образованию целлюлаз, расщепляющих растительную клетчатку, доля которой летом в составе рациона северного оленя возрастает.

Представители родов Clostridium и Blautia также относятся к целлюлозоразлагающим бактериям рубца жвачных, что объясняет достоверное увеличение их присутствия у северного оленя в летне-осенний период и свидетельствует о повышении потенциала микробного сообщества в отношении ферментации растительных полисахаридов. Кроме того, ранее сообщалось о значительном антимикробном действии усниновой кислоты лишайников ряд штаммов клостридий (5). Отметим, что полученные ранее результаты Т.H. Aagnes с соавт. (3) вступают в некоторое противоречие с нашими данными, поскольку эти авторы сообщали об увеличение представленности клостридий в зимний период, что, очевидно, также может объясняться видовыми метаболическими особенностями различных видов из рода Clostridium.

В исследовании F. Li c соавт. (41) при анализе микробиома рубца у 709 особей крупного рогатого скота отмечено, что присутствие комплекса бактерий (в том числе неидентифицируемых бактерий порядка Clostridiales, семейств Christensenellaceae, Mogibacteriaceae) прямо и положительно коррелирует с количеством ацетата, а бактерий рода Succiniclasticum - с количеством пропионата. Продемонстрированные авторами данные свидетельствуют о наличии определенных метаболических взаимосвязей между указанными микроорганизмами. Так, известно, что образование ацетата в рубце жвачных связано с процессами расщепления растительной клетчатки, тогда как пропионата - с метаболизмом крахмала (34). Таким образом, полученные нами результаты объясняют повышение обилия бактерий, синтезирующих ацетат, в летний период, когда основу питания северного оленя составляют растения, а продуцирующих пропионат - в зимний период, когда животные преимущественно поедают лишайники.

Помимо этого, в зимне-весенний период нами выявлено некоторое снижение представленности микроорганизмов, относящихся к филе Cyanobacteria (от $0,07 \pm 0,02 \%$ до $0 \%, r=0,00004, \mathrm{p}<0,05$ ). По результатам нашего исследования, как уже отмечалось, представленность цианобактерий в рубце особей северного оленя, обитающих на территории Ненецкого АО, как в летне-осенний, так и в зимне-весенний период, в целом оказалась минорной. Тем не менее, в других работах $(26,42)$ упоминалось о наличии в сообществе рубца северных оленей достаточно высокого числа цианобактерий, что представляется вполне логичным, поскольку цианобактерии относятся к симбионтам лишайников, составляющих до 10-15 \% летнего пастбищного рациона северных оленей и до 75\% - зимнего (43).

Интересные закономерности были отмечены нами для целого спектра условно-патогенных микроорганизмов, Полученные результаты показали, что в летне-осенний период в рубце северного оленя получают развитие многие микроорганизмы, которые относятся к возбудителям инфекций. При этом в зимне-весенний период представленность таких микроорганизмов достоверно снижается: для Erysipelotrichaceae - с 1,12 $\pm 0,17 \%$ в летне-

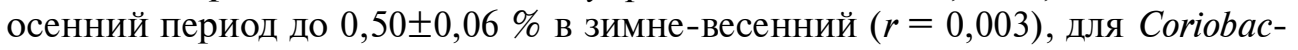

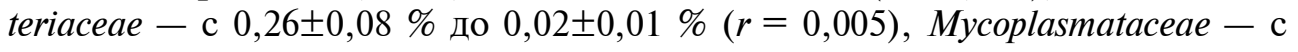




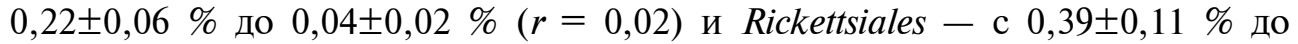
$0,10 \pm 0,02 \%(r=0,017)$; для всех $r \mathrm{p}<0,05$.

Полученные нами результаты в некоторой степени подтверждаются исследованием (44), в котором было обнаружено, что бактерии семейства Coriobacteriaceae - одни из наиболее чувствительных индикаторов, реагирующих на изменения в рубцовом микробиоме жвачных. Отметим, что выявленное нами достоверное увеличение представленности в рубце микоплазм семейства Mycoplasmataceae, в состав которого входит большое число патогенных бактерий, в летний период соответствует имеющимся сведениям о большей заболеваемости северных оленей именно в летний сезон (45).

Ранее были выявлены интересные закономерности положительной корреляции между обилием грамположительных бактерий семейства Erysiopelotrichaceae и особенностями кормления крупного рогатого скота (46). Подобно видам рода Lactobacillus, большинство представителей этого семейства ферментируют широкий спектр сахаров с образованием в основном молочной кислоты, что в результате повышает кислотность в рубце. Известно, что увеличение количества молочной кислоты в рубце жвачных приводит к нарушению переваривания клетчатки вследствие повышения pH среды и развитию лактатного ацидоза. Исследования J.E. Nocek c соавт. (47) показали, что повышение содержания молочной кислоты в рубце крупного рогатого скота может приводить к инфицированию фузобактериями вида Fusobacterium necrophorum и развитию некробактериозов в результате проникновения патогена через повреждения рубцового эпителия в кровь. Учитывая, что некробактериоз в стадах оленей носит сезонный (летний) характер, повышение численности представителей семейства Erysipelothrihaceae, которое мы выявили в указанный период года, представляется закономерным и интересным.

Таким образом, исследования северного оленя (Rangifer tarandus) ненецкой породы, проведенные нами в Российской Арктике, показали достоверное увеличение $\alpha$-биоразнообразия в летне-осенний период по сравнению с зимне-весенним, в том числе по числу OTUs ( $\mathrm{p}=0,0075542)$, индексам Chaol $(\mathrm{p}=0,0084612)$ и Шеннона $(\mathrm{p}=0,0000523)$. Статистически значимых различий по коэффициентам биоразнообразия бактериального сообщества рубца в связи с половозрастными особенностями у северного оленя мы не обнаружили. Независимо от сезона в содержимом рубца доминирующими были представители филумов Firmicutes и Bacteroidetes, менее представленными оказались бактерии филумов Proteobacteria, Actinobacteria, Verrucomicrobia, TM7, Spirochaete, Planctomycetes и SR1, доля других детектированных таксонов была минорна. Выявлен ряд значимых изменений в составе определенных таксономических групп бактерий в разные сезоны года. Так, в зимние-весенний период в рубце отмечается увеличение численности бактерий, участвующих в разложении полисахаридов лишайников, в том числе гемицеллюлозы (Butyrivibrio, $r=0,00007$; Ruminococcus, $r=0,01$ ), и лихенина (Succiniclasticum, $r=0,000000001$; Paraprevotellaceae, $r=0,00002$; Prevotella, $r=0,0005)$. В летние-осенний период повышается обилие микроорганизмов, ассоциированных с разложением растительной клетчатки, в том числе представителей родов Clostridium $(r=0,001)$, Blautia $(r=0,000006)$, неидентифицируемых родов из порядка Clostridiales $(r=0,000006)$, из семейств Christensenellaceae $(r=0,00001)$, Mogibacteriaceae $(r=0,007)$ и Prevotellaceae $(r=0,02)$. Также обнаружено, что в летний период в рубце северного оленя развивается группа микроорганизмов, которые относятся к возбудителям инфекционных процессов, включая бактерии семейств Erysipelotrichaceae $(r=0,003)$, Coriobacteriaceae $(r=0,005)$, Mycoplasmataceae $(r=0,02)$, 
Rickettsiales $(r=0,017)$. Для всех значений $r \mathrm{p}<0,05$.

Итак, полученные нами микробиомные профили северного оленя в целом соответствовали современным представлениям о микробиоте рубца жвачных животных. В летне-осенний период отмечено достоверное повышение показателей $\alpha$-биоразнообразия микробиома рубца по сравнению с зимне-весенним. Сопоставление $\beta$-разнообразия микробиоты рубца северных оленей продемонстрировало наличие выраженной кластеризации образцов по сезонам года. В зимне-весенний сезон выявлено достоверное увеличение обилия микроорганизмов, разлагаюших полисахариды лишайников, в том числе гемицеллюлозу (Butyrivibrio, Ruminococcus) и лихенин (Succiniclasticum, Paraprevotellaceae, Prevotella). В летние-осенний период отмечается достоверное увеличение доли целлюлозолитических бактерий Clostridium, Blautia, Clostridiales, Christensenellaceae, Mogibacteriaceae, Prevotellaceae. Кроме того, показано, что в летний период в рубце северного оленя развивается группа микроорганизмов, которые относятся к возбудителям инфекций (Erysipelotrichaceae, Coriobacteriaceae, Mycoplasmataceae, Rickettsiales). В целом, анализируя результаты исследования, можно сделать вывод о достаточно четкой ассоциации микробиома рубца северного оленя с особенностями питания в различные сезонные периоды. При этом различия в микробиоме рубца жвачных, определяющие адаптацию к экологическим условиям, проявляются на уровне минорных таксонов. Полученные данные могут быть использованы при разработке средств адаптации северных оленей к экологическим условиям территории, а также средств профилактики и лечения заболеваний, так или иначе связанных с сезонными изменениями микробиома рубца.

\section{ЛИТЕРАТУРА}

1. Morgavi D.P., Kelly W.J., Janssen P.H., Attwood G.T. Rumen microbial (meta)genomics and its application to ruminant production. Animal, 2013, 7(1): 184-201 (doi: 10.1017/S1751731112000419).

2. Mathiesen S.D., Mackie R.I., Aschfalk A., Ringø E., Sundset M.A. Microbial ecology of the digestive tract in reindeer: seasonal changes. In: Biology of growing animals. Vol. 2 Microbial ecology in growing animals /W.H. Holzapfel, P.J. Naughton, S.G. Pierzynowski, R. Zabielski, E. Salek (eds.). Elsevier Ltd., Edinburgh, 2005: 75-102 (doi: 10.1016/S1877-1823(09)70037-2).

3. Aagnes T.H., Sørmo W., Mathiesen S.D. Ruminal microbial digestion in free living, in captive lichen-fed and in starved reindeer (Rangifer tarandus tarandus) in winter. Applied and Environmental Microbiology, 1995, 61(2): 583-591.

4. Orpin C.G., Mathiesen S.D., Greenwood Y., Blix A.S. Seasonal changes in the ruminal microflora of the high-arctic Svalbard reindeer (Rangifer tarandus platyrhynchus). Applied and Environmental Microbiology, 1985, 50(1): 144-151.

5. Sundset M.A., Kohn A., Mathiesen S.D., Praesteng K.E. Eubacterium rangiferina, a novel usnic acid-resistant bacterium from the reindeer rumen. Naturwissenschaften, 2008, 95(8): 741-749 (doi: 10.1007/s00114-008-0381-0).

6. Kartsev V., Lichitsky B., Geronikaki A., Petrou A., Smiljkovic M., Kostic M., Radanovic O., Soković M. Design, synthesis and antimicrobial activity of usnic acid derivatives. Med. Chem. Commun., 2018, 9(5): 870-882 (doi: 10.1039/C8MD00076J).

7. Roach J.A.G., Musser S.M., Morehouse K., Woo J.Y.J. Determination of usnic acid in lichen toxic to elk by liquid chromatography with ultraviolet and tandem mass spectrometry determination. J. Agric. Food. Chem., 2006, 54(7): 2484-2490 (doi: 10.1021/jf052767m).

8. Dailey R.N, Montgomery D.L., Ingram J.T., Siemion R., Vasquez M., Raisbeck M.F. Toxicity of lichen secondary metabolite (+)-Usnic acid in domestic sheep. Veterinary Pathology, 2008, 45(1): 19-25 (doi: 10.1354/vp.45-1-19).

9. Palo R.T. Usnic acid, a secondary metabolite of lichens and its effect on in vitro digestibility in reindeer. Rangifer, 1993, 13(1): 39-43 (doi: 10.7557/2.13.1.1071).

10. Sundset M.A., Barboza P.S., Green T.K., Folkow L.P., Blix A.S., Mathiesen S.D. Microbial degradation of usnic acid in the reindeer rumen. Naturwissenschaften, 2010, 97: 273-278 (doi: 10.1007/s00114-009-0639-1).

11. Henderson G., Cox F., Ganesh S., Jonker A., Young W., Global Rumen Census Collaborators, Janssen P.H. Rumen microbial community composition varies with diet and host, but a core microbiome is found across a wide geographical range. Scientific Reports, 2015, 5: 14567 (doi: 
10.1038/srep14567).

12. Fonty G., Joblin K., Chavarot M., Roux R., Naylor G., Michallon F. Establishment and development of ruminal hydrogenotrophs in methanogen-free lambs. Applied and Environmental Microbiology, 2007, 73(20): 6391-6403 (doi: 10.1128/AEM.00181-07).

13. Sundset M.A., Præsteng K.E., Cann I.K.O., Mathiesen S.D., Mackie R.I. Novel rumen bacterial diversity in two geographically separated sub-species of reindeer. Microb. Ecol., 2007, 54(3): 424438 (doi: 10.1007/s00248-007-9254-x).

14. Crater A.R., Barboza P.S., Forster R. Regulation of rumen fermentation during seasonal fluctuations in food intake of muskoxen. Comparative Biochemistry and Physiology. Part A, Molecular \& Integrative Physiology, 2007, 146(2): 233-241 (doi: 10.1016/j.cbpa.2006.10.019).

15. Rustomo B., AlZahal O., Odongo N., Duffield T.F., McBride B.W. Effects of rumen acid load from feed and forage particle size on ruminal $\mathrm{pH}$ and dry matter intake in the lactating dairy cow. Journal of Dairy Science, 2006, 89(12): 4758-4768 (doi: 10.3168/jds.S0022-0302(06)72525-5).

16. Kleen J.L., Hooijer G.A., Rehage J., Noordhuizen J.P. Subacute ruminal acidosis (SARA): a review. Journal of Veterinary Medicine Series A, 2003, 50(8): 406-414 (doi: 10.1046/j.14390442.2003.00569.x).

17. McEwan N.R., Abecia L., Regensbogenova M., Adam C.L., Findlay P.A., Newbold C.J. Rumen microbial population dynamics in response to photoperiod. Letters in Applied Microbiology, 2005, 41(1): 97-101 (doi: 10.1111/j.1472-765X.2005.01707.x)

18. Uyeno Y., Sekiguchi Y., Tajima K., Takenaka A., Kurihara M., Kamagata Y. An rRNA-based analysis for evaluating the effect of heat stress on the rumen microbial composition of Holstein heifers. Anaerobe, 2010, 16(1): 27-33 (doi: 10.1016/j.anaerobe.2009.04.006).

19. Romero-Pérez G.A., Ominski K.H., McAllister T.A., Krause D.O. Effect of environmental factors and influence of rumen and hindgut biogeography on bacterial communities in steers. Applied and Environmental Microbiology, 2011, 77(1): 258-268 (doi: 10.1128/AEM.01289-09).

20. Olsen M.A., Aagnes T.H., Mathiesen S.D. The effect of timothy silage on the bacterial population in rumen fluid of reindeer (Rangifer tarandus tarandus) from natural summer and winter pasture. FEMS Microbiology Ecology, 1997, 24(2): 127-136 (doi: 10.1111/j.1574-6941.1997.tb00429.x).

21. Wang T.Y., Chen H.L., Lu M.J., Chen Y.C., Sung H.M., Mao C.T., Cho H.Y., Ke H.M., Hwa T.Y., Ruan S.K., Hung K.Y., Chen C.K., Li J.Y., Wu Y.C., Chen Y.H., Chou S.P., Tsai Y.W., Chu T.C., Shih C.A., Li W.H., Shih M.C. Functional characterization of cellulases identified from the cow rumen fungus Neocallimastix patriciarum W5 by transcriptomic and secretomic analyses. Biotechnol. Biofuels, 2011, 4: 24 (doi: 10.1186/1754-6834-4-24).

22. Fonty G., Joblin K.N. Rumen anaerobic fungi: their role and interactions with other rumen microorganisms in relation to fiber digestion. In: Physiological aspects of digestion and metabolism in ruminants. Academic Press, Toronto, ON, 1990: 665-680.

23. Sundset M.A., Edwards J.E., Cheng Y.F., Senosiain R.S., Fraile M.N., Northwood K.S., Præsteng K.E., Glad T., Mathiesen S.D., Wright A.D.G. Molecular diversity of the rumen microbiome of Norwegian reindeer on natural summer pasture. Microb. Ecol., 2009, 57(2): 335-348 (doi: 10.1007/s00248-008-9414-7).

24. Sundset M.A., Edwards J.E., Cheng Y.F., Senosiain R.S., Fraile M.N., Northwood K.S., Praesteng K.E., Glad T., Mathiesen S.D., Wright A.D. Rumen microbial diversity in Svalbard reindeer, with particular emphasis on methanogenic archaea. FEMS Microbiology Ecology, 2009, 70(3): 553-562 (doi: 10.1111/j.1574-6941.2009.00750.x).

25. Salgado-Flores A., Hagen L.H., Ishaq S.L., Zamanzadeh M., Wright A.D.G., Pope P.B., Sundset M.A. Rumen and cecum microbiomes in reindeer (Rangifer tarandus tarandus) are changed in response to a lichen diet and may affect enteric methane emissions. PLoS ONE, 2016, 11(5): e0155213 (doi: 10.1371/journal.pone.0155213).

26. Полежаев А.Н., Беркутенко А.Н. Определитель кормовых растений северного оленя: Магаданская область. Магадан, 1981.

27. Мотовилов К.Я., Булатов А.П, Позняковский П.М., Ланцева Н.Н., Миколайчик И.Н. Экспертиза кормов и кормовых добавок. Новосибирск, 2004.

28. Caporaso J.G., Kuczynski J., Stombaugh J., Bittinger K., Bushman F.D., Costello E.K., Fierer N., Peca A.G., Goodrich J.K., Gordon J.I., Huttley G.A., Kelley S.T., Knights D., Koenig J.E., Ley R.E., Lozupone C.A., McDonald D., Muegge B.D., Pirrung M., Reeder J., Sevinsky J.R., Turnbaugh P.J., Walters W.A., Widmann J., Yatsunenko T., Zaneveld J., Knight R. QIIME allows analysis of high-throughput community sequencing data. Nature Methods, 2010, 7: 335-336 (doi: 10.1038/nmeth.f.303).

29. Oliveros J.C. Venny. An interactive tool for comparing lists with Venn's diagrams. 2007. Режим доступа: http://bioinfogp.cnb.csic.es/tools/venny/index.html. Без даты.

30. Warton D.I., Wright T.W., Wang Y. Distance-based multivariate analyses confound location and dispersion effects. Methods in Ecology and Evolution, 2012, 3(1): 89-101 (doi: 10.1111/j.2041210X.2011.00127.x).

31. Morgavi D.P., Kelly W.J., Janssen P.H., Attwood G.T. Rumen microbial (meta)genomics and its application to ruminant production. Animal, 2013, 7(1): 184-201 (doi: 10.1017/S1751731112000419). 
32. Person S.J., White R.G., Luick J.R. Determination of nutritive value of reindeer-caribou range, In: Proceedings of the 2nd International Reindeer and Caribou Symposium /E. Reimers, E. Gaare, S. Skjenneberg (eds.). Direktoratet for vilt og ferskvannsfisk, Trondheim, Norway, 1980: 224-239.

33. Church D.C. Ruminant animal: digestive physiology and nutrition. Prentice Hall, New Jersey, 1993.

34. Hungate R.E. The rumen and its microbes. Academic Press, NY, 1966.

35. Hackmann T.J., Spain J.N. Invited review: ruminant ecology and evolution: perspectives useful to ruminant livestock research and production. Journal of Dairy Science, 2010, 93(4): 1320-1334 (doi: 10.3168/jds.2009-2071).

36. Peng S., Yin J., Liu X., Jia B., Chang Z., Lu H., Jiang N., Chen Q. First insights into the microbial diversity in the omasum and reticulum of bovine using Illumina sequencing. J. Appl. Genetics, 2015, 56(3): 393-401 (doi: 10.1007/s13353-014-0258-1).

37. Smith C.C.R., Snowberg L.K., Gregory C.J., Knight R., Bolnick D.I. Dietary input of microbes and host genetic variation shape among-population differences in stickleback gut microbiota. ISME J., 2015, 9(11): 2515-2526 (doi: 10.1038/ismej.2015.64).

38. Fiere N. Embracing the unknown: disentangling the complexities of the soil microbiome. Nature Reviews Microbiology, 2017, 15: 579-590 (doi: 10.1038/nrmicro.2017.87).

39. Shen J., Zheng L., Chen X., Han X., Cao Y., Yao J. Metagenomic analyses of microbial and carbohydrate-active enzymes in the rumen of dairy goats fed different rumen degradable starch. Frontiers in Microbiology, 2020, 11: 1003 (doi: 10.3389/fmicb.2020.01003).

40. Li Z.P., Liu H.L., Guang Y.L., Bao K., Wang K.Y., Xu C., Yang Y.F., Yang H.F., Wright A.D.G. Molecular diversity of rumen bacterial communities from tannin-rich and fiber-rich forage fed domestic Sika deer (Cervus nippon) in China. BMC Microbiol., 2013, 13: 151 (doi: 10.1186/14712180-13-151).

41. Li F., Li C., Chen Y., Liu J. Host genetics influence the rumen microbiota and heritable rumen microbial features associate with feed efficiency in cattle. Microbiome, 2019, 7: 92 (doi: 10.1186/s40168-019-0699-1).

42. Zielińska S., Kidawa D., Stempniewicz L., Łoś M., Łoś J.M. New insights into the microbiota of the Svalbard Reindeer Rangifer tarandus platyrhynchus. Frontiers in Microbiology, 2016, 7: 170 (doi: 10.3389/fmicb.2016.00170).

43. Mathiesen S.D, Haga Ø.E, Kaino T., Tyler N.J.C. Diet composition, rumen papillation and maintenance of carcass mass in female Norwegian reindeer (Rangifer tarandus tarandus) in winter. Journal of Zoology, 2000, 251(1): 129-138 (doi: 10.1111/j.1469-7998.2000.tb00598.x).

44. Zhou M., Peng Y., Chen Y., Klinger C., Masahito O., Liu J., Guan L. Assessment of microbiome changes after rumen transfaunation: implications on improving feed efficiency in beef cattle. $M i$ crobiome, 2018, 6: 62 (doi: 10.1186/s40168-018-0447-y).

45. Казановский Е.С., Карабанов В.П., Клебенсон К.А. Болезни северных оленей. Сыктывкар, 2011.

46. Morita H., Shiratori C., Murakami M., Takami H., Toh H., Kato Y., Nakajima F., Takagi M., Akita H., Masaoka T., Hattori M. Sharpea azabuensis gen. nov., sp. nov., a Gram-positive, strictly anaerobic bacterium isolated from the faeces of thoroughbred horses. International Journal of Systematic and Evolutionary Microbiology, 2008, 58(12): 2682-2686 (doi: 10.1099/ijs.0.65543-0).

47. Nocek J.E. Bovine acidosis: implications on laminitis. Journal of Dairy Science, 1997, 80: 10051028 (doi: 10.3168/jds.S0022-0302(97)76026-0).

$100 О$ «БИОТРОФ+»,

192284 Россия, г. Санкт-Петербург, Загребский б-р, 19, корп. 1, e-mail: ilina@biotrof.ru $₫$, deniz@biotrof.ru, filippova@biotrof.ru, timur@biotrof.ru,dubrowin.a.v@yandex.ru,sdv@biotrof.ru,

natalia-iv-nov@rambler.ru, georg-laptev@rambler.ru;

2ФГБУ Северо-Западный иентр междисциплинарных

исследований проблем продовольственного обеспечения,

196608 Россия, г. Санкт-Петербург-Пушкин, ш. Подбельского, 7,

e-mail: layshev@mail.ru, alyuzhakov@mail.ru;

ЗФГБНУ Федеральный исследовательский иентр

комплексного изучения Арктики им. Н.П. Лаверова РАН,

Нарьян-Марская сельскохозяйственная станция,

166004 Россия, Ненецкий автономный округ, г. Нарьян-Мар,

ул. Рыбников, 1А,

e-mail:nmshos@atnet.ru, vylcko.yury@yandex.ru
Поступила в редакцию

15 апреля 2020 года

Sel'skokhozyaistvennaya biologiya [Agricultural Biology], 2020, V. 55, № 4, pp. 697-713

\title{
VARIATION IN THE RUSSIAN ARCTIC REINDEER (Rangifer tarandus) RUMEN MICROBIOME RELATED TO SEASON CHANGE
}

\author{
L.A. Ilina ${ }^{1}$, V.A. Filippova ${ }^{1}$, K.A. Layshev ${ }^{2}$, E.A. Yildirim ${ }^{1}$, T.P. Dunyashev ${ }^{1}$, \\ E.A. Brazhnik', A.V. Dubrovin ${ }^{1}$, D.V. Sobolev ${ }^{1}$, D.G. Tiurina ${ }^{1}$, N.I. Novikova ${ }^{1}$,
}




\title{
G.Yu. Laptev', A.A. Yuzhakov', T.M. Romanenko ${ }^{3}$, Yu.P. Vylko
}

${ }^{1}$ JSC Biotrof+, 19, korp. 1, Zagrebskii bulv., St. Petersburg, 192284 Russia, e-mail ilina@biotrof.ru ( $\square$ corresponding author),deniz@biotrof.ru, filippova@biotrof.ru, timur@biotrof.ru, dubrowin.a.v@yandex.ru, sdv@biotrof.ru, nataliaiv-nov@rambler.ru, georg-laptev@rambler.ru;

${ }^{2}$ Northwest Center for Interdisciplinary Research of Food Security Problems, 7, sh. Podbel'skogo, St. Petersburg-Pushkin, 196608 Russia, e-mail layshev@mail.ru, alyuzhakov@mail.ru;

${ }^{3}$ Laverov Federal Center for Integrated Arctic Research (FCIARctic) RAS, Naryan-Mar Agro-Experimental Station, 1a, ul. Rybnikov, Naryan-Mar, Nenets AO, 166004 Russia, e-mail nmshos@atnet.ru, vylcko.yury@yandex.ru ORCID:

Ilina L.A. orcid.org/0000-0003-2789-4844

Laishev K.A. orcid.org/0000-0003-2490-6942

Yildirim E.A. orcid.org/0000-0002-5846-5105

Filippova V.A. orcid.org/0000-0001-8789-9837

Dunyashev T.P. orcid.org/0000-0002-3918-0948

Dubrovin A.V. orcid.org/0000-0001-8424-4114

The authors declare no conflict of interests

Acknowledgements:

Supported financially by Russian Science Foundation for project No. 17-76-20026 "Rumen microbiocenosis in Rangifer tarandus of the Russian Arctic as a fundamentals for promising animal biotechnologies"

Received April 15, 2020

Sobolev D.V. orcid.org/0000-0002-3238-979X

Novikova N.I. orcid.org/0000-0002-9647-4184

Laptev G.Yu. orcid.org/0000-0002-8795-6659

Yuzhakov A.A. orcid.org/0000-0002-0633-4074

Romanenko T.M. orcid.org/0000-0003-0034-7453

Vylko Yu.P. orcid.org/0000-0002-6168-8262

\begin{abstract}
Reindeer (Rangifer tarandus) is a large Holarctic herbivore animal, the habitat of which, including its existence at low temperatures and poor diets, has led to the evolutionary development of their unique rumen microbiota, which is necessary for the efficient assimilation of the Arctic flora. In winter, lichens rich in secondary metabolites which can influence the representatives of the microbial consortium of the digestive tract, make up a large proportion of reindeer fodder plants. The toxic effects of certain lichen metabolites (e.g., usnic acid) on a number of microorganisms (Clostridiales, Enterococcus, Staphylococcus aureus, Escherichia coli, etc.) as well as ruminants (elk) were previously reported. However, little is known about the effect of lichen consumption on the reindeer rumen microbiome. Using molecular analysis, we were the first to study the seasonal patterns of the formation of the microbial communities of the rumen of the reindeer Rangifer tarandus, living in the Russian Arctic. The purpose of the study was to compare the composition of the bacterial community of the reindeer rumen in the summer-autumn and winter-spring periods using the method of NGS-sequencing. In the analysis of microbial communities, biodiversity, taxonomic structure, and the relationship of these indicators with the characteristics of reindeer nutrition in connection with seasonal changes were evaluated. Samples of the rumen content were collected in the summer-autumn and winter-spring periods in 2017-2018 from 20 Nenets reindeer (calves 4-8 months old and adult animals 3-6 years old, $n=3$ per each age group) in the Nenets Autonomous District (AD). Seasonal differences, in contrast to gender and age, turned out to be the main factor influencing the reindeer rumen bacterial community, which, most likely, is due to differences in the composition of the pasture diet. In the summerautumn period, a significant increase in the $\alpha$-biodiversity of the rumen microbiome was noted compared to the winter-spring time for the number of OTUs, Chaol and Shannon indices. A comparison of the $\beta$-diversity of the reindeer rumen microbiota composition has demonstrated the presence of pronounced cluster formation for samples collected in different seasons of the year. Despite the fact that in the winter period the diet of reindeer was mainly represented by lichens which are not typical food for other ruminants (such as cattle, sheep, etc.), it was interesting to note that, on the whole, the obtained microbiome profiles correspond to modern ideas about the ruminant rumen microbiota. Nevertheless, during different seasonal periods, significant changes in the representation of a number of taxa were noted, the clearest of which were detected for microorganisms associated with feed polysaccharide fermentation. So, in the winter-spring season, a significant increase in microorganisms that decompose polysaccharides of lichens, including hemicellulose (Butyrivibrio, Ruminococcus), and lichenin (Succiniclasticum, Paraprevotellaceae, and Prevotella). In the summer-autumn period, a significant increase in the proportion of cellulolytic bacteria (Clostridium, Blautia, Clostridiales, Christensenellaceae Mogibacteriaceae, and Prevotellaceae) is noted. In addition, it has been shown that in the summer period a whole spectrum of microorganisms that belong to bacterial pathogens, including Erysipelotrichaceae, Coriobacteriaceae, Mycoplasmataceae, and Rickettsiales, proliferate in the reindeer rumen. On the whole, the results obtained allow us to conclude that the reindeer rumen microbiome is quite clearly associated with nutritional characteristics during various seasonal periods, which determine adaptation to environmental conditions.
\end{abstract}

Arctic.

Keywords: Rangifer tarandus, reindeer, rumen, microbiome, seasonal changes, NGS, Russian 